\title{
Image and Reputation of Yalova City: A Study on Yalova University Students
}

\section{Cevdet Kizll}

Assistant Professor, Istanbul Medeniyet University, Department of Management, Turkey | cevdetkizil@yahoo.com

\begin{abstract}
Alican Atalan
Undergraduate Student, Yalova University, Business Administration Department in English | alicanatalan@hotmail.com
\end{abstract}

Volume 5 No 2 (2015) ｜ ISSN 2158-8708 (online) ｜ DOI 10.5195/emaj.2015.87 | http://emaj.pitt.edu |

\begin{abstract}
Recently, the image of a country and city has become a core competitive asset for the government and local authorities and this core competitive asset plays a critical role for domestic and foreign tourists, businessmen, residents of the city, neighbouring cities, investors, entrepreneurs and also the university students. Based on the competitive asset of city image and reputation, the perception needs an effort from a marketing perspective in order to improve the strategies for enhancing quality of life. The aim of this research is to evaluate the city image of Yalova from the eye of Yalova university students. For this purpose, image perception of students on the advantages of city, abstract image elements and residents of the city have been investiageted. The data of research have been collected through the questionnaire methodology. This study is run on 200 students as the research sample. In light of the results of the survey, the overall image perception of students about Yalova city and its residents are determined to be at medium level. Location of Yalova has a very positive perception, while intercity transportation, nature and weather conditions have a positive perception. The city is considered as peaceful, safe and clean, but expensive. Residents of Yalova are evaluated as peaceful. It is also found that, infrastructures and superstructures enhancing the Yalova city image should be improved.
\end{abstract}

Keywords: Image, Reputation, Marketing, Yalova, University

\section{(cc) BY}

New articles in this journal are licensed under a Creative Commons Attribution 3.0 United States License.

\section{ULIS D-Sonk}

This journal is published by the University Library System of the University of Pittsburgh as part

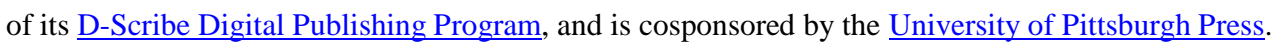




\section{Image and Reputation of Yalova City: A Study on Yalova University Students}

\section{Cevdet Kızıl \\ Alican Atalan}

\section{Introduction}

In a globalizing world, the rivalry is not only among products, but it is also among cities. This rivalry plays a critical role to get a competitive advantage and not to get behind other cities. The mentioned rivalry obliges the cities to possess a strong image for remaining in this competition. Strong city image and reputation are also musts for surviving from the intense competition field where cities struggle to take a position for domestic and foreign tourists, businessmen, residents of a city, investors, entrepreneurs and also university students. Thus, marketing professionals should also concentrate on the city image to improve marketing operations towards their target group.

There are many critical standards to choose a city and one of these standards is expressed as city image (Bakan, 2008:293). The image is defined as a virtual presentation of an object, an event, a condition, a person, a group, a city or a country (Demirel, 2014:230-241). According to Kotler, the city image is an integration of belief, ideas and impression in people's mind toward a specific location (Kotler et al, 1993).

City image is also defined as a set of belief structured and composed by people (Apaydın, 2011); (Kotler, Hamlin, Rein and Haider, 2001). A city image consists of the whole features of unseen and visible objects towards a city. There are many different elements influencing the image and perception of a city. These elements are characteristics of inhabits of the city, city's location or diplomatic appearance, the intensity of population, ratio of crime, socioeconomic status and employment status, city's position in the world, its history, films and TV series that were filmed in a city, recreation opportunities and touristic-cultural destinations as well as appearance of a city (Avraham, 2004).

The city image produces an intangible output with a tangible input. Also, the city image is generated and formed by the experience toward a city, word of mouth among friends and social network, articles from the newspapers, TV shows, documentaries, published resources, information about a city and communication tools such as marketing. Together with these elements, the city image is structured in minds negatively or positively (Gecikli, 2012); (Demirel, 2014).

As Kotler expressed, a city's image may be a positive and desirable, negative and poor, complex (consists of both positive and negative image) or conflicting. A city image can be categorized in two different aspects such as " rich image " and " poor image". Rich image is that, people who live far away from a certain city have a lot of information about that city and this information source arrives from different sources or personal experiences. Poor image is that, there is less information about a certain city and personal experiences are limited from different sources (Avraham, 2004). The perception and focus points about a city also often differentiates among individuals. For instance, one individual may view a city as an investable area for the future, while another individual can concentrate on the tax rates and educated work-force around the area.

The image and reputation create a competitive asset for the city. At that point, how to manage this image and perception needs a marketing process and strategy. To implement these processes and strategies, the government or city municipality needs to have a strong marketing perfective. That is why the city marketing subject is an eye-catching one in the recent years. City marketing is defined as a phenomenon to satisfy the demand of a certain target group and to contribute the city image for enhancing related perception. Each city has to have a strong image in minds, that should be supported with successful strategies. The city marketing at this point includes the relationship between identity, image and brand (Akdoğan \& Karkın, 2010).

Throughout the history, the marketing of cities has become more important, since this issue is critical to attract foreign direct investment (FDI). The cities are currently accepted and considered as a product for the business life since they provide infrastructure, workforce, land, facilities and social life for the inhabitants. (Bennet \& Koudelova, 2001).

Determining the outstanding features of a city is extremely significant in the city marketing. By the help of situational analysis, after determining the outstanding features of a city, the mentioned city should be differentiated from the competitors. Differentiation can be applied in any field such as the nature of city, leisure facilities, history, location, characteristics of inhabitants, universities or traditional food culture (Apaydın, 2011). 
The strategic image management is a critical step for the city image. There are also two steps of measuring the city image. At the first step, target groups are identified and at the second step, features of a city and common interests of target groups are determined (Apaydın, 2011). Elements affecting the city image and features for measuring city image are shown below on Table 1.

Table 1. Elements Affecting the City Image and Features for Measuring City Image

\begin{tabular}{|c|c|}
\hline$\underline{\text { Elements }}$ & Futures \\
\hline $\begin{array}{l}\text { The natural } \\
\text { sources }\end{array}$ & $\begin{array}{cl}\text { Climate } & \\
\text { - } & \text { Landscape } \\
\text { - } & \text { Nature }\end{array}$ \\
\hline Infrastructure & $\begin{aligned} \text { Airports, } & \text { Roads and Ports } \\
\text { - } & \text { Public and Private } \\
& \text { Transportation } \\
\text { - } & \text { Health and Wellness } \\
& \text { Facilities } \\
\text { - } & \text { Communication Services } \\
\text { - } & \text { Commercial } \\
\text { - } & \text { Infrastructure } \\
& \text { Physical Conditions of } \\
& \text { Buildings }\end{aligned}$ \\
\hline $\begin{array}{c}\text { Tourism } \\
\text { Infrastructure }\end{array}$ & $\begin{aligned} & \text { Hotels and Restaurants } \\
& \text { - } \text { Bars and Clubs } \\
& \text { - } \text { Facilities of } \\
& \text { Transportation } \\
& \text { - } \text { Tourism Destinations } \\
& \text { - } \text { Information Services } \\
& \text { - } \text { Trips and Tours } \\
& \text { Organizations }\end{aligned}$ \\
\hline $\begin{array}{c}\text { Entertainment } \\
\text { Locations }\end{array}$ & $\begin{array}{ll}\text { Parks } & \\
\text { - } & \text { Recreation and Sport } \\
\text { Activities }\end{array}$ \\
\hline $\begin{array}{c}\text { History, Cultre } \\
\text { and Art }\end{array}$ & $\begin{array}{ll}\text { - } & \text { Museums } \\
\text { - } & \text { Monuments } \\
\text { - } & \text { Festival } \\
\text { - } & \text { Concerts } \\
\text { - } & \text { Crafts } \\
\text { - } & \text { Foligion } \\
\text { - } & \text { Food } \\
\text { - } & \text { Culture }\end{array}$ \\
\hline
\end{tabular}

\begin{tabular}{|c|c|}
\hline $\begin{array}{c}\text { Political and } \\
\text { Economic } \\
\text { Factors }\end{array}$ & $\begin{array}{ll}\text { - } & \text { Political Stability } \\
\text { - } & \text { Political Tendency } \\
\text { - } & \text { Economy } \\
\text { - } & \text { Security } \\
\text { - } & \text { Prices }\end{array}$ \\
\hline Nature & $\begin{array}{ll}\text { - } & \text { Beauty of cities } \\
\text { - } & \text { Cleanliness } \\
\text { - } & \text { Population } \\
\text { - } & \text { Air/Noise Pollution } \\
\text { - } & \text { Traffic Jam }\end{array}$ \\
\hline $\begin{array}{c}\text { Social } \\
\text { Environment }\end{array}$ & $\begin{array}{ll}\text { - } & \text { Hospitality of City } \\
\text { - } & \text { Inhabitants } \\
\text { - } & \text { Discrimination } \\
\text { - } & \text { Quality of Life } \\
\text { - } & \text { Language Barriers } \\
\text { - } & \end{array}$ \\
\hline $\begin{array}{c}\text { Atmosphere of } \\
\text { City }\end{array}$ & $\begin{array}{ll}\text { - } & \text { Luxurious Places } \\
\text { - } & \text { Fashion } \\
\text { - } & \text { Famous Locations } \\
\text { - } & \text { Family Locations } \\
\text { - } & \text { Exotic Locations } \\
\text { - } & \text { Mystic Locations } \\
\text { - } & \text { Locations to Relax } \\
\text { - } & \text { Stress Locations }\end{array}$ \\
\hline
\end{tabular}

Resource: Apaydın, F. (2011). Şehir Pazarlaması. Nobel Yayınları

There are seven different target groups for city marketing when city marketers consider composing their strategies. These target groups are as follows: (Apaydın, 2011); (Kotler, Hamlin, Rein and Haider, 2001).

1. Public: Most of the city managements give importance and priority to gain the attention of new residents who are going to provide tax revenues. Thus, how the mentioned group of individuals perceive the city plays a critical role.

2. Visitors: Visitors increase the trade volume by utilizing the facilities of accommodation and doing shopping in the city. In order to take advantage of opportunities for enhancing trade volume, it is a necessary activity and operation for city managements to present services and products for visitors.

3. Managers: It is significant how executives of firms perceive the city. Because, company owners and managers make investments in cities, which foster the development of these locations seriously.

4. Domestic Investors: Domestic investors and real estate investors also lend a great deal of funds to 
certain cities. Their contribution for a strong city image can also never be underestimated.

5. Entrepreneurs: Small and medium sized enterprises (SMEs) have a strong impact on the development and value of a city. In this respect, operations of these organizations in cities and their success rates create an investable area for other entrepreneurs. That way, more entrepreneurs are attracted to cities in increasing rates.

6. Foreign Investors: Foreign investors build a communication bridge with other cities in the world, they enhance the value of the cities and serve as an important factor to attract foreign direct investment (FDI).

7. Specialists: Creating a remarkable city also brings in experts and specialities from all over the world, who have a strong impact on the improvement of city.

As observed, these seven diverse target groups perceive the cities differently and all of them have separate demands. Thus, city markets should be able to plan and execute various marketing strategies for each target group. Planning and executing a wide spectrum of marketing strategies can be realized by the government and municipalities employing personnel coming from different backgrounds and who have unorthodox job experiences.

\section{Data and Methodology}

The purpose of this research is to evaluate the image perception of Yalova city from the eye of Yalova University students. Study consists 200 students who study in 4 faculties and 1 vocational school of Yalova University. The mentioned 4 faculties where this research is run are Faculty of Economics and Administrative Sciences, Faculty of Law, Faculty of Engineering and Faculty of Religious Studies (Faculty of Islamic Sciences). Students subject to this study were chosen randomly and it was made sure that these students were not originally from Yalova, since that would create bias and subjectivity.

There are many different methods to measure city image of residents and related target groups. These techniques can be listed as questionnaire, focus group meeting and in depth interview (Avraham, 2004). Data are collected using the questionnaire method for this study. In terms of survey questions, two former studies are taken as reference, which are "City Brand and the Measurement of Brand Image: A Survey in Afyonkarahisar" (Özdemir and Karaca, 2009) and "Burdur City Image: A Case Study on Mehmet Akif Ersoy University Students" (Demirel, 2014 ).
The survey includes four different sections for respondents. At first section, six different questions related to demographic factors are directed to respondents (Yalova University students) in order to identify their faculty/vocational school, type of education, gender, class (year), original region (hometown) and accommodation. At the second part of survey, eighteen different questions are directed to respondents for evaluating the opportunities (advantages) of Yalova city. Then, at the third part of survey, seven questions are directed to measure the intangible image (abstract elements) and characteristics of Yalova city.

At the last part of survey (fourth section), fifteen questions are directed in order to learn the perception of students towards Yalova city residents. Each part of the survey are designed to evaluate the diverse feautures of Yalova city, except the first section which is related with demographic factors. Survey uses a 5-point Likert Scale, ranging from strongly disagree to strongly agree.

SPSS (Statistical Program For Social Science) 20 for Windows was used in order to process and analyze the research data. Finally, the arithmetic means were calculated and considered for this research, to identify the image perception of Yalova city and its inhabitants (residents). The numerical intervals of arithmetic means used for interpretation are listed below:

- If $1.0 \leq X<1.8$, the image perception of participant is very low

- If $1.8 \leq X<2.6$, the image perception of participant is low

- If $2.6 \leq X<3.4$, the image perception of participant is medium/undecided

- If $3.4 \leq X<4.2$, the image perception of participant is high

- If $4.2 \leq X<5.0$, the image perception of participant is very high. 


\section{Results}

Demographic characteristics and data of participants are provided below on Table 2 .

Table 2. Demographic Characteristics and Data of Participants

\begin{tabular}{|c|c|c|c|}
\hline Variables & $\begin{array}{l}\text { Groups/Sub- } \\
\text { Sections }\end{array}$ & $\mathbf{N}$ & $\%$ \\
\hline \multirow[t]{6}{*}{ Faculty } & $\begin{array}{l}\text { Faculty of } \\
\text { Law }\end{array}$ & 4 & 2.0 \\
\hline & $\begin{array}{l}\text { Faculty of } \\
\text { Religious } \\
\text { Studies } \\
\text { (Islamic } \\
\text { Studies) }\end{array}$ & 1 & 0.5 \\
\hline & $\begin{array}{l}\text { Faculty of } \\
\text { Engineering }\end{array}$ & 45 & 22.5 \\
\hline & $\begin{array}{l}\text { Faculty of } \\
\text { Economics } \\
\text { and } \\
\text { Administrative } \\
\text { Sciences }\end{array}$ & 99 & 49.5 \\
\hline & $\begin{array}{l}\text { Vocational } \\
\text { School }\end{array}$ & 51 & 25.5 \\
\hline & Total & 200 & 100 \\
\hline \multirow[t]{3}{*}{$\begin{array}{l}\text { Type of } \\
\text { Education }\end{array}$} & $\begin{array}{l}\text { Daytime } \\
\text { Education }\end{array}$ & 185 & 92.5 \\
\hline & $\begin{array}{l}\text { Evening } \\
\text { Education }\end{array}$ & 15 & 7.5 \\
\hline & Total & 200 & 100 \\
\hline \multirow[t]{3}{*}{ Gender } & Male & 111 & 55.5 \\
\hline & Female & 89 & 44.5 \\
\hline & Total & 200 & 100 \\
\hline \multirow[t]{5}{*}{ Class (Year) } & 1st Year & 53 & 26.5 \\
\hline & 2nd Year & 95 & 47.5 \\
\hline & 3rd Year & 17 & 8.5 \\
\hline & 4th Year & 35 & 17.5 \\
\hline & Total & 200 & 100 \\
\hline
\end{tabular}

\begin{tabular}{|c|c|c|c|}
\hline \multirow[t]{8}{*}{$\begin{array}{l}\text { Region } \\
\text { (Hometown) }\end{array}$} & $\begin{array}{l}\text { Mediterranean } \\
\text { Region }\end{array}$ & 18 & 9.0 \\
\hline & $\begin{array}{l}\text { Marmara } \\
\text { Region }\end{array}$ & 121 & 60.5 \\
\hline & $\begin{array}{l}\text { Aegean } \\
\text { Region }\end{array}$ & 13 & 6.5 \\
\hline & $\begin{array}{l}\text { Central } \\
\text { Anatolia } \\
\text { Region }\end{array}$ & 13 & 6.5 \\
\hline & $\begin{array}{l}\text { Black Sea } \\
\text { Region }\end{array}$ & 17 & 8.5 \\
\hline & $\begin{array}{l}\text { Eastern } \\
\text { Anatolia } \\
\text { Region }\end{array}$ & 13 & 6.5 \\
\hline & $\begin{array}{l}\text { Southeastern } \\
\text { Anatolia } \\
\text { Region }\end{array}$ & 5 & 2.5 \\
\hline & Total & 200 & 100 \\
\hline \multirow[t]{5}{*}{$\begin{array}{l}\text { Accom } \\
\text { modation }\end{array}$} & $\begin{array}{l}\text { House for } \\
\text { Rent }\end{array}$ & 81 & 40.5 \\
\hline & Dormitory & 25 & 12.5 \\
\hline & Hostel & 45 & 22.5 \\
\hline & Other & 49 & 24.5 \\
\hline & Total & 200 & 100 \\
\hline
\end{tabular}

Table 2 related to demographic characteristics and data of participants show that, a great majority of students who did take the survey are from faculty of economics and administrative sciences (49.5\%). That is followed by vocational school students $(25.5 \%)$, faculty of engineering students (22.5\%), faculty of law students (2\%) and faculty of religious studies (islamic studies) students $(0.5 \%)$. Also, most of the students who took the survey are daytime education students (92.5\%). However, only $7.5 \%$ of university students are evening education students.

Moreover, $55.5 \%$ of respondents (university students) are males while $45.5 \%$ are females. Besides, $47.5 \%$ of respondents are 2 nd year students. This followed by 1 st year students $(26.5 \%)$, 4 th year students (17.5\%) and 3rd year students (8.5\%). Furthermore, a high ratio of university students are from Marmara region $(60.5 \%)$. Then comes the university students from Mediterranean region (9\%), Black Sea region (8.5\%), 
Aegean region (6.5\%), Central Anatolia region (6.5\%), Eastern Anatolia region $(6.5 \%)$ and Southeastern Anatolia region (2.5\%). Finally, most university students taking the survey live in houses for rent $(40.5 \%)$. The remaining students live in other type of residences (24.5\%), hostels $(22.5 \%)$ and dormitories $(12.5 \%)$.

The study also measured and evaluated the image perceptions on opportunies (advantages) of Yalova city as mentioned earlier. Indeed, each survey question at this section was designed to measure the advantages and disadvantages of Yalova city. Results concerning the image perceptions on opportunities (advantages) of Yalova city are indicated on Table 3.

Table 3. Image Perceptions on Opportunities (Advantages) of Yalova City

\begin{tabular}{|l|l|l|l|}
\hline Characteristic & Mean* & $\begin{array}{l}\text { Standard } \\
\text { deviation }\end{array}$ & $\begin{array}{l}\text { Perception } \\
\text { level }\end{array}$ \\
\hline Location is good & 4.57 & 5.78 & Very high \\
\hline Nature is good & 3.69 & 1.00 & High \\
\hline $\begin{array}{l}\text { Intercity } \\
\text { transportation is } \\
\text { good }\end{array}$ & 3.62 & 1.16 & High \\
\hline $\begin{array}{l}\text { Weather conditions } \\
\text { are good }\end{array}$ & 3.54 & 1.05 & High \\
\hline $\begin{array}{l}\text { Urban } \\
\text { transportation is } \\
\text { good }\end{array}$ & 3.30 & 1.22 & Medium \\
\hline $\begin{array}{l}\text { Health facilities are } \\
\text { good }\end{array}$ & 3.13 & 1.08 & Medium \\
\hline $\begin{array}{l}\text { Food and beverages } \\
\text { are good }\end{array}$ & 3.12 & 1.03 & Medium \\
\hline $\begin{array}{l}\text { Cultural events are } \\
\text { plenty } \\
\text { plenty }\end{array}$ & 2.78 & 1.06 & Medium \\
\hline $\begin{array}{l}\text { History is rich } \\
\text { plenty }\end{array}$ & 2.71 & 1.12 & Medium \\
\hline $\begin{array}{l}\text { Education } \\
\text { opportunities are } \\
\text { good }\end{array}$ & 2.69 & 1.13 & Medium \\
\hline $\begin{array}{l}\text { Accommodation } \\
\text { facilities are good }\end{array}$ & 2.64 & 1.18 & \\
\hline
\end{tabular}

\begin{tabular}{|l|l|l|l|}
\hline $\begin{array}{l}\text { Industry is } \\
\text { developed }\end{array}$ & 2.61 & 1.07 & Medium \\
\hline $\begin{array}{l}\text { Planned } \\
\text { urbanization exists }\end{array}$ & 2.55 & 0.98 & Low \\
\hline $\begin{array}{l}\text { Services of } \\
\text { municipality are } \\
\text { successful }\end{array}$ & 2.54 & 1.15 & Low \\
\hline $\begin{array}{l}\text { Shopping facilities } \\
\text { are plenty }\end{array}$ & 2.28 & 1.16 & Low \\
\hline $\begin{array}{l}\text { Recreation facilities } \\
\text { are plenty }\end{array}$ & 2.25 & 1.10 & Low \\
\hline Total & 53.24 & 24.43 & Medium \\
\hline $\begin{array}{l}\text { General Average } \\
\text { (Mean) }\end{array}$ & 2.95 & 1.35 & \\
\hline
\end{tabular}

Perception Level: $1.0 \leq X<1.8$ ( Very Low); $1.8 \leq X$ $<2.6$ ( Low)

$2.6 \leq X<3.4$ ( Medium) $3.4 \leq X<4.2$ (High); $4.2 \leq X$ $<5.0$ ( Very High)

According to the survey results about image perceptions on opportunities (advantages) of Yalova City, location is considered very ideal for respondents. This is generally because Yalova is very close to big cities such as Istanbul, Kocaeli (İzmit) and Bursa. The nature, intercity transportation and weather conditions are considered ideal by respondents based on the mean scores.

However, some characteristics of Yalova city such as urban transportation, health facilities, food and beverages, cultural events, history, education opportunities, accommodation facilities, sport events, art events and industry are considered normal (at medium level) by respondents. This means that, improvements in Yalova city can be made on these issues. Moreover, according to survey respondents, characteristics of Yalova city like planned urbanization, services of municipality, shopping facilities and recreation facilities are poor. In other words, survey respondents rate the mentioned characteristics low as a result of the questionnaire. Thus, improvements should definitely be made at these fields. Also, in general, image perceptions on opportunities (advantages) of Yalova city have a medium rating with a mean of 2.95 and a standard deviation of 1. 35 . 
Third section of this study assessed the abstract elements of Yalova city. For this purpose, some characteristics about Yalova city was listed and respondents were asked to evaluate the listed features. Table 4 shows the results related to respondents' answers regarding abstract elements of Yalova city.

Table 4. Image Perceptions on Abstract Elements of Yalova City

\begin{tabular}{|c|c|c|c|}
\hline Characteristic & Mean* & $\begin{array}{l}\text { Standard } \\
\text { Deviation }\end{array}$ & $\begin{array}{l}\text { Perception } \\
\text { Level }\end{array}$ \\
\hline Peaceful & 3.95 & 1.04 & High \\
\hline Clean & 3.38 & 1.13 & High \\
\hline Safe & 3.35 & 1.11 & High \\
\hline Outward & 3.30 & 1.11 & Medium \\
\hline Modern & 3.21 & 1.06 & Medium \\
\hline Developed & 2.78 & 1.10 & Medium \\
\hline Inexpensive & 2.08 & 1.08 & Low \\
\hline Total & 22.05 & 7.63 & \\
\hline Total Average & 3.15 & 1.09 & Medium \\
\hline \multicolumn{4}{|c|}{$\begin{array}{l}\text { The perception Level: } 1.0 \leq X<1.8 \text { ( Very Low) } ; 1.8 \leq X \\
<2.6 \text { ( Low) }\end{array}$} \\
\hline \multicolumn{4}{|c|}{$\begin{array}{l}2.6 \leq X<3.4 \text { ( Medium) } 3.4 \leq X<4.2 \text { (High); } 4.2 \leq X \\
<5.0 \text { ( Very High) }\end{array}$} \\
\hline \multicolumn{4}{|c|}{$\begin{array}{l}2.6 \leq X<3.4 \text { ( Medium) } 3.4 \leq X<4.2 \text { (High); } 4.2 \leq X \\
<5.0 \text { ( Very High) }\end{array}$} \\
\hline
\end{tabular}

Based on the results listed on Table 4, the strongest abstract elements of Yalova city is its peacefulness, cleanness and safeness. But, the city has an average rating in terms of its outward, modern and developed characteristics. In other words, university students as respondents are undecided whether Yalova is an outward, modern and developed city or not. However, questionnaire respondents generally believe that Yalova is an expensive city for university students, since the mean is 2.08 for this factor. At last, the abstract elements of Yalova city are rated medium by respondents with an average score (mean) of 3.15 and a standard deviation of 1.09 .

Fourth section of this research included the measurement of image perception of residents of Yalova. Thus, some questions were directed for particular characteristics of Yalova City's residents. Table 5 below shows the image perception of university students as respondents concerning the characteristics of Yalova city residents.

Table 5. Image Perceptions of Residents of Yalova City

\begin{tabular}{|c|c|c|c|}
\hline Characteristic & Mean* & $\begin{array}{l}\text { Standard } \\
\text { Deviation }\end{array}$ & $\begin{array}{l}\text { Perception } \\
\text { Level }\end{array}$ \\
\hline Peaceful & 3.61 & 1.12 & High \\
\hline Warm Blooded & 3.20 & 1.09 & Medium \\
\hline Friendly & 3.13 & 1.11 & Medium \\
\hline Tolerant & 3.19 & 1.12 & Medium \\
\hline Educated & 3.15 & 1.03 & Medium \\
\hline Boring & 3.14 & 1.12 & Medium \\
\hline Kind & 3.14 & 1.02 & Medium \\
\hline Helpful & 3.03 & 1.13 & Medium \\
\hline Honest & 2.97 & 0.95 & Medium \\
\hline Traditional & 2.85 & 1.07 & Medium \\
\hline Innovative & 2.85 & 1.02 & Medium \\
\hline Hard-working & 2.83 & 1.03 & Medium \\
\hline Entrepreneur & 2.80 & 0.96 & Medium \\
\hline Generous & 2.79 & 1.03 & Medium \\
\hline Religious & 2.67 & 1.03 & Medium \\
\hline Total & 45.35 & 15.83 & \\
\hline Total Average & 3.02 & 1.05 & Medium \\
\hline \multicolumn{4}{|c|}{$\begin{array}{l}\text { The perception Level : } 1.0 \leq X<1.8 \text { ( Very Low); } 1.8 \\
X<2.6 \text { ( Low) } \\
2.6 \leq X<3.4 \text { ( Medium) } 3.4 \leq X<4.2 \text { (High); } 4.2 \leq X \\
<5.0 \text { ( Very High) }\end{array}$} \\
\hline
\end{tabular}


Parallel to the indicators on Table 5, it should be noted that respondents perceive residents of Yalova as very peaceful. That is advantageous related tp the image perception of Yalova city residents. On the other hand, all other characteristics of Yalova city residents are rated medium. University students as respondents did not rate warm blooded, friendly, tolerant, educated, boring, kind, helpful, honest, traditional, innovative, hard-working, entrepreneur, generous and religious characteristics as high nor low. Overall, image perception of residents of Yalova city is medium with an average (mean) of 3.02 and a standard deviation of 1.05 .

\section{Conclusion}

The images of countries and cities have become a core competitive asset for both the governments and city municipalities. This core competitive asset has a critical impact on composing strategies to improve image perceptions. A strong city image is perceived as a supportive element in order to enhance the overall perspective of city towards public, students, domestic and foreign tourists, business people, managers, entrepreneurs, investors, specialists and residents.

In this content, how an image is going to be perceived needs an effort from a marketing perspective and applying correct strategies. According to Philip Kotler, the concept of city image is structured and accomplished by overall thoughts, feelings and biases toward a specific city. Also, the city image is said to be formed as a result of certain group of beliefs.

This study aimed measuring the image perception of Yalova city from the viewpoint of Yalova University students. For this purpose, a survey had been conducted as a part of this resarch in order to expose the perception level of Yalova and its residents. According to the results of research, location of Yalova is evaluated as the most important element and most valuable factor of city. In other words, respondents think that the location of Yalova city is a critical advantage and opportunity. Moreover, it is determined that nature, weather conditions and intercity transportation are other important assets of Yalova city and they are perceived positive in terms of city image.

On the opposite side, urban transportation, health facilities, food and beverages, cultural events, history, education opportunities, accommodation facilities, sport events, art events and industry in Yalova are considered normal (at medium level). Improvements may be considered for mentioned points. Plus, planned urbanization, services of municipality, shopping facilities and recreation facilities are rated poor. So, steps to triggger developments at these areas should be taken. Overall, image perception on opportunities (advantages) of Yalova city is medium (normal).

In terms of image perception on abstract elements, Yalova is rated as a peaceful, clean and safe city. That is a very desirable result for Yalova city, considering the image perception. But, respondents are not certain whether Yalova ia an outward, modern and developed city. More importantly, based on the thoughts of Yalova University students as respondents, Yalova is an expensive city.

Finally, in the context of image perceptions of residents of Yalova city, local people are considered to be peaceful. That is a desired and advantageous result for the image perception of Yalova city. But warm blooded, friendly, tolerant, educated, boring, kind, helpful, honest, traditional, innovative, hard-working, entrepreneur, generous and religious characteristics of Yalova residents are rated medium (undecided) by university students as respondents.

In conclusion, it is observed that image perception of Yalova city is strong and desireable for specific factors. Definitely, there are still other factors related to the image perception of Yalova city waiting for improvement. It is recommended that the government, municipality and Yalova University to work together for improving the image perception of Yalova city further. This will help to attract more students, business people, domestic investment, foreign direct investment (FDI) and tourists to Yalova city.

\section{REFERENCES}

Akdoğan, Ş. ve Karkın, G. (2010). "Şehir

Pazarlaması Kapsamında Bir İmaj

Çalışması; S Sivas Ö̈neği”.

I.Disiplinerarası Turizm Araştırma

Kongresi, 549.

Anholt, S. (2010). "Definitions of place branding-Working towards a resolution”. Place Branding and Public Diplomacy. 
Apaydın, F. (2011). "Şehir Pazarlaması". Nobel Yayınları.

Avraham, E. (2004). "Medi strategies for improving an unfavorable city image". 471479.

Bennet, R. and Koudelova, R. (2001). "Image selection and the marketing of downtown areas in London and New York". The international journal of public sector management, 205-220.

Demirel, M. (2014). "Burdur City Image: A Case Study on Mehmet Akif Ersoy University". Mehmet Akif Ersoy Sosyal Bilimler Enstitüsü Dergisi, 230241.

Gecikli, F. (2012). "Şehir İmajı: Amasya şehri üzerine bir uygulama”. Ankara: Fenomen Yayınları.

Kavaratzis, M., and Ashworth, G. (2008). "Place marketing: How did we get here and where are we going ?". Journal of place management and development, 150-165.

Kotler, P., and Gertner, D. (2002). "Country as brand, product and beyond: A place marketing and brand management perspective". Brand Management, 249261.
Kotler, P., Hamlin, M. A., Rein, I., and Haider, D. H. (2001). "Marketing Asian Places: Attracting Investment, Industry and Tourism to Cities, States and Nations". Singapore: John Wiley \& Sons Pte. Ltd.

Özdemir, Ş., and Karaca, Y. (2009). “Kent Markası ve Marka İmajının Ölçümü: Afyonkarahisar Kenti İmajı Üzerine Bir araştırma”. Afyon Kocatepe Üniversitesi İ.İ.B.F Dergisi, 113-134.

Sağdıç, M. (2014). “Üniversite öğrencilerinin İstanbul'a ilişkin algılarının şehir imajı açısından analizi”. Turkish Studies, 1267-1283.

Zenker, S., Knubben, E., and Beckmann, S. C. (2010). "Your city, my city, their city, our city". 6th International Conference Thought Leader in Brand Management. 